\title{
Oral squamous cell carcinoma: metastasis, potentially associated malignant disorders, etiology and recent advancements in diagnosis [version 1; peer review: 3
}

\section{approved]}

\begin{abstract}
Amr Bugshan (D), Imran Farooq
Department of Biomedical Dental Sciences, College of Dentistry, Imam Abdulrahman Bin Faisal University, Dammam, 31441, Saudi Arabia
\end{abstract}

V1 First published: 02 Apr 2020, 9:229

https://doi.org/10.12688/f1000research.22941.1

Latest published: 02 Apr 2020, 9:229

https://doi.org/10.12688/f1000research.22941.1

\section{Abstract}

Oral squamous cell carcinoma (OSCC) is a commonly occurring head and neck cancer. It has a high prevalence in certain parts of the world, and is associated with a high mortality rate. In this review, we describe metastasis related to OSCC, and disorders that could lead to OSCC with common etiological factors. In addition, a brief account of the diagnosis of OSCC and role of salivary biomarkers in its early detection has also been highlighted. Google Scholar and PubMed search engines were searched with keywords including "oral squamous cell carcinoma”, "OSCC", "oral cancer", "potentially malignant disorders in oral cavity", "etiological factors of OSCC", "diagnosis of OSCC", and "salivary biomarkers and OSCC" to gather the literature for this review. The review concludes that OSCC has the potential for regional as well as distant metastasis, and many potentially malignant diseases can transform into OSCC with the help of various etiological factors. Diagnosis of OSCC involves traditional biopsy, but salivary biomarkers could also be utilized for early recognition.

Keywords

Oral squamous cell carcinoma, Metastasis, Potentially malignant disorders, Etiological factors of OSCC, Diagnosis of OSCC

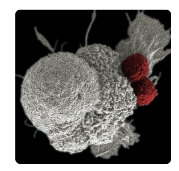

This article is included in the Oncology

gateway.

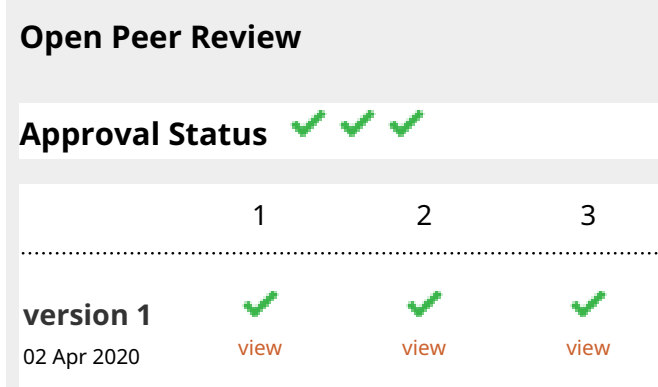

1. Faisal Aljofi, University of Maryland,

Baltimore, USA

2. Ambreen Rehman (D), Queen Mary

University of London, London, UK

Fatima Qadir (D), Queen Mary University of London, London, UK

3. Ali Leghari, Baqai Medical University, Karachi, Pakistan

Any reports and responses or comments on the article can be found at the end of the article. 
Corresponding author: Imran Farooq (drimranfarooq@gmail.com)

Author roles: Bugshan A: Conceptualization, Data Curation, Formal Analysis, Investigation, Methodology, Project Administration, Resources, Software, Supervision, Validation, Visualization, Writing - Original Draft Preparation, Writing - Review \& Editing; Farooq I: Conceptualization, Data Curation, Formal Analysis, Investigation, Methodology, Project Administration, Resources, Software, Supervision, Validation, Visualization, Writing - Original Draft Preparation, Writing - Review \& Editing

Competing interests: No competing interests were disclosed.

Grant information: The author(s) declared that no grants were involved in supporting this work.

Copyright: (c) 2020 Bugshan A and Farooq I. This is an open access article distributed under the terms of the Creative Commons Attribution License, which permits unrestricted use, distribution, and reproduction in any medium, provided the original work is properly cited.

How to cite this article: Bugshan A and Farooq I. Oral squamous cell carcinoma: metastasis, potentially associated malignant disorders, etiology and recent advancements in diagnosis [version 1; peer review: 3 approved] F1000Research 2020, 9:229 https://doi.org/10.12688/f1000research.22941.1

First published: 02 Apr 2020, 9:229 https://doi.org/10.12688/f1000research.22941.1 


\section{Introduction}

One of the commonest forms of cancer is head and neck cancer $^{1}$. Its prevalence is different in various parts of the world; in unindustrialized countries, like India, it is the cancer most commonly diagnosed in male patients whereas in the Western world, it is responsible for $1-4 \%$ of all cancers ${ }^{2}$. Lip, oral cavity, and oropharynx combined were responsible for about 4,47,751 new cancer cases with an estimated $2,28,389$ deaths in 2018, which accounts for $2.4 \%$ of all cancer deaths $^{3}$. Among other cancers, head and neck cancer is fourteenth in terms of incidence but thirteenth in terms of mortality ${ }^{3}$. The Asian continent has the highest incidence and mortality rates of oral cavity and oropharynx cancers among all other countries ${ }^{4}$. More than $90 \%$ of cancer cases in head and neck region are OSCCs (Figure 1$)^{5}$. OSCC develops in the oral cavity and oropharynx and can occur due to many etiological factors, but smoking and alcohol remain the most common risk factors especially in the Western world ${ }^{6}$. In South Asian countries, consumption of smokeless tobacco and areca nut products are the main etiological factors associated with $\mathrm{OSCC}^{7}$. Gene mutations may also cause cancer development in the pharynx and oral cavity; however, no specific gene has been identified in OSCCs ${ }^{8}$. Activation of proto-oncogenes (ras, myc, EGFR) or inhibition of tumor suppressor genes (TB53, pRb, p16) by environmental factors such as smoking, irradiation, and viral infection may increase the risk of oral and oropharynx $\mathrm{OSCC}^{9}$. Most of the oral and oropharynx OSCC cases occur in elderly male patients, with tonsils and tongue being the most commonly affected sites ${ }^{10}$.

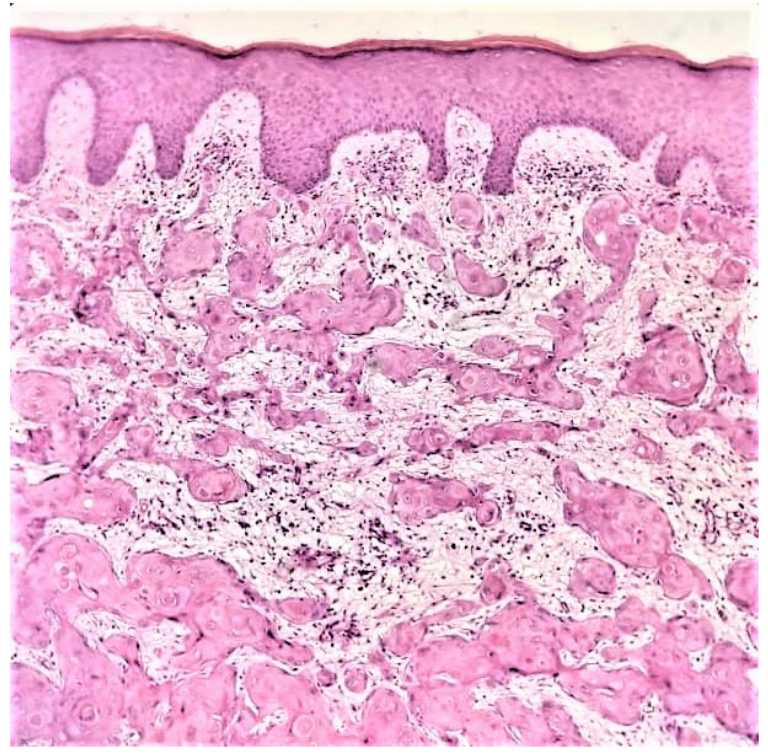

Figure 1. Photomicrograph showing well differentiated oral squamous carcinoma cells displaying nuclear pleomorphism, mitosis, and high number of keratin pearls. Image is courtesy of Dr. Faraz Kasti (Oral Pathology Division, College of Dentistry, Imam Abdulrahman Bin Faisal University, Dammam, Saudi Arabia). Written informed consent was obtained from the individual for publication.
In this review we have briefly described metastasis related to OSCC, some disorders that could transform into OSCC with associated common etiological factors. In addition, a brief account of the diagnosis of OSCC and role of salivary biomarkers in its early detection has also been highlighted. Google Scholar and PubMed search engines were searched with keywords including "oral squamous cell carcinoma", "OSCC", "oral cancer", "potentially malignant disorders in oral cavity", "etiological factors of OSCC", "diagnosis of OSCC", and "salivary biomarkers and OSCC" and our search revealed $500+$ results. All the articles in languages other than English and conference abstracts/presentations were excluded. Finally, 77 articles were selected for this study and included in our review.

\section{Metastasis}

Metastasis could be of two types; regional and/or distant metastasis, as discussed below.

\section{Regional metastasis}

In terms of regional metastasis, nodal metastasis transpires when tumor cells at the primary site penetrate lymphatic channels and migrate to regional lymph nodes in the neck, forming a micrometastasis ${ }^{11}$. Lymph node metastasis is a critical prognostic indicator for oral and oropharyngeal carcinomas $^{12}$. The most common site for OSCC metastasis is cervical lymph nodes, and it reduces the survival rate by $50 \%{ }^{13,14}$. Cancer cells usually spread to the lymph nodes on the same side of the cancer primary site. However, contralateral or bilateral lymph nodes metastasis can rarely occur?. In histopathology, tumor cells dissemination outside the lymph node capsule making the prognosis worse and reducing patient survival rate $^{11}$. Therefore, a thorough head and neck lymph node inspection and palpation for all first-time patients should be performed to help in early detection of cancer, which will increase the chances for successful treatment and improve $\operatorname{prognosis}^{15}$.

\section{Distant metastasis}

For distant metastasis, carcinomas require certain biological events in order to spread from the primary tumor site to an anatomically distant site. Several steps are required for cancer cells to spread from their original site to the metastatic one, as shown in the invasion-metastasis cascade ${ }^{16}$. The cascade starts at the primary tumor site where the cancer cells locally breach the basement membrane to invade the surrounding extracellular matrix and connective tissue ${ }^{17}$. Then, the tumor cells move to lymphatic or blood vessels and travel to distant metastatic sites. At this point, tumor cells start to extravasate from the vessels into the stroma of the metastatic site $^{18}$. Initially, tumor cells use the metastatic tissue microenvironment to grow and form micrometastasis. Then, tumor cells expand and colonize to start their own proliferative program and form macroscopic metastasis $^{16}$. The lung is the commonest site for distant metastasis for head and neck OSCC ${ }^{19}$. However, metastasis to other organs, such as mediastinal nodes, liver, and bone, have been also reported ${ }^{19,20}$. Distant metastasis worsens the prognosis and reduces the chances of successful treatment ${ }^{21}$. 
Positive regional lymph node involvement, extracapsular invasion of tumor cells, and human papilloma virus negativity are key factors that increase the risk of primary tumor cell dissemination to distant organs ${ }^{20}$.

\section{Potentially malignant disorders (PMDs) transforming into OSCC}

Early detection of cancer is a key factor for improved prognosis and increased patient survival rate. Even though the oral cavity can be easily examined and assessed by direct visual inspection, most OSCC cases are not identified early ${ }^{22}$. This most likely ensues because patients do not seek dental care on a regular basis and most oral cancers in the early stages are asymptomatic ${ }^{22}$. Moreover, dentists may not be aware of the different clinical presentations of OSCC and misdiagnose cancers as reactive or benign lesions ${ }^{23}$. In order to help early discovery and increase the prognosis of cancers, patient awareness about regularly visiting dentists and education of dental practice staff to carefully examine the patients should be raised $^{24}$.

There are many PMDs in the oral cavity that have the predisposition to transform into OSCC, a few of which are discussed below in detail.

\section{Leukoplakia}

The World Health Organization describes "a clinical diagnosis that include any white lesion (plaque or patch) on the oral mucosa that cannot be considered clinically or pathologically as any other disease is a leukoplakia"25. In 1975, Waldron et al. reviewed 3,256 clinical cases defined as "leukoplakia" and found that around $80 \%$ of the cases are diagnosed microscopically as either hyperkeratosis or acanthosis ${ }^{26}$. They also reported that about $17 \%$ of the cases were potentially malignant lesions $(12.2 \%$ mild to moderate dysplasia and $4.5 \%$ severe dysplasia or carcinoma in situ) and the diagnosis of OSCC was made in about $3 \%$ of the cases that were received with the diagnosis of "leukoplakia"26. Earlier, Bewley and Farwell also reported that OSCC can occur from malignant transformation of leukoplakia ${ }^{27}$. Therefore, early detection of leukoplakia is key to stop their transformation into aggressive malignant OSCC, which could be hard to treat.

\section{Proliferative verrucous leukoplakia (PVL)}

PVL is a destructive form of oral leukoplakia that clinically presents as multiple, slowly spreading white lesions with high reappearance rate and high probability of malignant transformation $^{28}$. A study of 47 patients diagnosed with PVL showed that around $40 \%$ of the patients developed malignant lesions (OSCC or verrucous carcinoma) during follow-up (within 2 years) ${ }^{29}$. Bagán et al. also reported in their study that there was a high occurrence of patients with PVL developing OSCC in different sites (gingiva and palate being most common $)^{30}$.

\section{Erythroleukoplakia}

Erythroleukoplakia (sometimes called speckled leukoplakia) is a mixed red and white lesion that most likely exhibits more advanced dysplastic changes in histopathological examination compared to leukoplakia ${ }^{31}$. This lesion usually has irregular margins, and Candida colonization on these lesions is also common $^{32}$. The chances of speckled leukoplakia for malignant transformation is $18-47 \%$.

\section{Erythroplakia}

Defined as "Any red lesion of the oral mucosa that cannot be clinically diagnosed as any other condition is called erythroplakia" ${ }^{34}$. True erythroplakia is a more alarming clinical finding compared to leukoplakia. ${ }^{9}$ A retrospective study showed that $91 \%$ of 58 cases clinically observed as "erythroplakia" were diagnosed as OSCC (51\%), carcinoma in situ or severe dysplasia $(40 \%)$, or mild or moderate epithelial dysplasia $(9 \%)^{35}$. Erythroplakia and leukoplakia are usually predecessors of OSCC $^{36}$ and sometimes also seen adjacent to an OSCC lesion $^{37}$.

Oral submucous fibrosis (OSMF)

OSMF occurs due to progressive fibrosis of the oral mucosa due to chronic use of areca nut ${ }^{38}$. Patients diagnosed with OSMF are likely to develop malignant $\mathrm{OSCC}^{39}$. A prospective study was carried out on 371 patients with microscopically proven diagnosis of OSCC and it was reported that around 30\% of the patients (112) had a history of $\mathrm{OSMF}^{40}$. However, a study carried out by Chourasia et al. reported an incidence of $4.2 \%$ for patients with OSMF transforming to $\mathrm{OSCC}^{39}$.

\section{Oral lichen planus (OLP)}

An immune-mediated condition that clinically may present as reticular white areas that may or may not be associated with erosive and ulcerative lesions ${ }^{41}$. There is still debate whether to consider OLP as a PMDs. A previous study in which the data of 20,095 patients was assessed reported $1.1 \%$ incidence of OLP patients developing OSCC ${ }^{42}$. It should be noted however, that erosive type of OLP and patients with history of smoking and alcohol use are likely to suffer from transformation of OLP to $\mathrm{OSCC}^{42,43}$. It was reported in another previous study that tumour recurrence rate of OSCC is higher in patients who had previous OLP than the patients with primary $\mathrm{OSCC}^{44}$

\section{Common etiological factors of OSCC}

Various etiological factors of OSCC have been reported in the literature. The most common are summarized below.

\section{Cigarette smoking}

Cigarette smoking helps in the spread of tumors by suppressing immunity and tumor suppressor genes, most importantly p53 and $\mathrm{PTEN}^{45}$. In an earlier study, al-Idrissi reviewed 65 patients with established diagnosis of head and neck OSCC and reported that the majority of these patients were men and $41.5 \%$ were smokers $^{46}$. In another study from China, which included 210 cases, a strong association between long term smoking and OSCC was reported ${ }^{47}$. Llewelyn and Mitchell from Scotland reported in their study that out of 454 patients with confirmed oral cancer, $60 \%$ were smokers and over $95 \%$ of those lesions were $\mathrm{OSCC}^{48}$. 


\section{Alcohol consumption}

A strong connection between drinking alcohol and several cancer types has been described in the literature ${ }^{49}$. The synergetic effects of alcohol consumption and tobacco smoke increases the risk of OSCC by making the oral epithelium more permeable, dissolving tobacco, and promoting its penetration ${ }^{50}$. However, chronic use of alcohol alone may lead to OSCC via several mechanisms, including DNA adduct formation, generation of ethanol-related reactive oxygen metabolites, and interference with the DNA-repair mechanism ${ }^{51}$.

\section{Shammah consumption}

The consumption of shammah is on the rise in many countries ${ }^{52}$. It is a combination of powdered smokeless tobacco with ingredients like lime, pepper, ash, and flavoring agents, and people use it by placing it in buccal cavity till the taste penetrates $^{53}$. In a previous study from Jazan, Saudi Arabia, in which data from 132 patients were recorded, it was reported that the most common cancer detected was OSCC followed by thyroid cancer $^{52}$. Another study carried out on Yemeni shammah users concluded that there was a strong association between daily shammah usage and formation of leukoplakia $(\mathrm{a} P M D)^{54}$.

\section{Chewing of khat}

Khat is a plant that is mostly used for chewing and is a mixture of cathine and norephidrine ${ }^{55}$. In a previous study, the prevalence of its consumption was found to be $23.1 \%$ among university students of Jazan, Saudi Arabia ${ }^{56}$. In an earlier case report of one patient, a strong affiliation between khat chewing and growth of OSCC was reported ${ }^{57}$. Sawair et al. also reported a strong relationship between khat chewing and development of OSCC in their study, which consisted of 649 Yemeni patients ${ }^{58}$. Lukandu et al. reported from Kenya that chronic khat chewing could lead to abnormal epithelial thickening of oral mucosa and increased keratinization, and fibrosis ${ }^{59}$.

\section{Shisha (water pipe) smoking}

Shisha is commonly available in restaurants, cafes, and other eatery shops in many countries and it contains a high concentration of nicotine, tar, and carbon monoxide ${ }^{60}$. In water pipe smoking, smoke passes through water and there is a general idea that it is less harmful then cigarette smoking ${ }^{61}$. In a recently published review, a strong association between water pipe smoking and head and neck cancers was reported ${ }^{62}$. Zaid et al. reported in a study from Syria and Lebanon that p53 gene mutations were associated water pipe smoking in $\mathrm{OSCC}^{63}$. Al-Amad carried out a study in Jordan, which revealed that $36 \%$ of their sample who had oral cancer had a habit of water pipe smoking ${ }^{64}$.

\section{Diagnosis of OSCC}

Exfoliative cytology

Exfoliative cytology is a simple method that could prove useful in early identification of oral cancer as it is based on collection of exfoliated cells for microscopic examination ${ }^{65}$. It should be noted however that cells can suffer exfoliation normally and/or in the presence of a benign or malignant disease $^{66}$. Therefore, the most accurate diagnosis of OSCC should only be made by biopsy.

\section{Biopsy}

Despite the new diagnostic modalities in oral cancer detection, biopsy and histopathologic analysis remain the gold standard to diagnose $\mathrm{OSCC}^{67}$. An adequate biopsy technique involves local anaesthesia administration, having sufficient width and depth of the excised tissue, correct handling of the tissue, and submission without contamination to aid an accurate definitive $\operatorname{diagnosis}^{68}$.

\section{Role of salivary biomarkers in detection of OSCC}

The typical diagnosis of OSCC is made by clinical oral examination followed by biopsy of the suspected tissue ${ }^{69}$. Unfortunately, due to this approach, most OSCC cases either go undetected (at an early stage) or are diagnosed at advanced stages $^{70}$. In addition, due to late diagnosis, metastasis for OSCC is very common, resulting in a 5-year survival rate of less than $50 \%{ }^{71}$.

Human saliva could be used for the early detection of various diseases $^{72}$. OSCC is very common and its early detection can improve the prognosis significantly ${ }^{73}$. It has been suggested by various researchers that a specific group of protein biomarkers are increased in saliva of individuals with $\mathrm{OSCC}^{74}$. Franzmann et al. reported CD44 as a probable biomarker of head and neck cancer whereas, Nagler et al. described Cyfra-21-1 and cancer antigen-25 to be potential biomarkers for oral cancer $^{74,75}$. In an earlier study including 395 patients, Elashoff et al. stated an increase in expression of all seven transcriptomes and three proteins as possible markers for $\mathrm{OSCC}^{76}$. They also reported an increase in the levels of IL-8 and subcutaneous adipose tissue in saliva exhibiting maximum levels of sensitivity and specificity to diagnose $\mathrm{OSCC}^{77}$. Similarly, ArellanoGarcia et al. described that expression of IL8 and IL1 $\beta$ were increased in saliva of patients with OSCC as compared with control patients ${ }^{78}$. Gleber-Netto et al. performed a study involving 180 patients and reported that among the proteomic markers, IL8 and IL1 $\beta$ concentration was greater in OSCC patients when compared with control and dysplasia patients ${ }^{79}$. Awasthi performed a study that included 64 individuals with diagnosed cases of OSCC, pre-malignant conditions, and healthy controls ${ }^{80}$. It was revealed from the results of that study that patients with OSCC had increased salivary levels of Cyfra-21-1, lactate dehydrogenase, and total protein concentration in comparison to other groups $^{80}$.

\section{Conclusion}

Our review concludes that OSCC has the potential for regional as well as distant metastasis. Many PMDs can transform into OSCC with the help of various etiological factors. Diagnosis of OSCC involves traditional biopsy, but salivary biomarkers could also be utilized for its early diagnosis.

\section{Data availability}

No data is associated with this article. 
1. Capparuccia L, Tamagnone L: Semaphorin signaling in cancer cells and in cells of the tumor microenvironment--two sides of a coin. J Cell Sci. 2009; 122(Pt 11): $1723-36$.

PubMed Abstract | Publisher Full Text

2. Joshi $P$, Dutta $S$, Chaturvedi $P$, et al.: Head and neck cancers in developing countries. Rambam Maimonides Med J. 2014; 5(2): e0009. PubMed Abstract | Publisher Full Text | Free Full Text

3. https://gco.iarc.fr/today/data/factsheets/populations/682-saudi-arabia-factsheets.pdf [Accessed: $2^{\text {nd }}$ March, 2020].

4. Al-Jaber A, Al-Nasser L, El-Metwally A: Epidemiology of oral cancer in Arab countries. Saudi Med J. 2016; 37(3): 249-55.

PubMed Abstract | Publisher Full Text | Free Full Text

5. Tandon $\mathrm{P}$, Dadhich $\mathrm{A}$, Saluja $\mathrm{H}$, et al:: The prevalence of squamous cel carcinoma in different sites of oral cavity at our Rural Health Care Centre in Loni, Maharashtra - a retrospective 10-year study. Contemp Oncol (Pozn). 2017; 21(2): 178-183.

PubMed Abstract | Publisher Full Text | Free Full Text

6. Graham S, Dayal H, Rohrer T, et al:: Dentition, diet, tobacco, and alcohol in the epidemiology of oral cancer. J Natl Cancer Inst. 1977; 59(6): 1611-8. PubMed Abstract | Publisher Full Text

7. Muttagi SS, Chaturvedi $P$, Gaikwad R, et al.: Head and neck squamous cell carcinoma in chronic areca nut chewing Indian women: Case series and review of literature. Indian J Med Paediatr Oncol. 2012; 33(1): 32-5. PubMed Abstract | Publisher Full Text | Free Full Text

8. Krishna A, Singh S, Kumar V, et al:: Molecular concept in human oral cancer. Natl J Maxillofac Surg. 2015; 6(1): 9-15. PubMed Abstract | Publisher Full Text | Free Full Text

9. Neville BW, Damm DD, Allen CM, et al.: Oral and maxillofacial pathology. St. Louis, Mo: Saunders/Elsevier. 2009 Reference Source

10. Weatherspoon DJ, Chattopadhyay A, Boroumand S, et al:: Oral cavity and oropharyngeal cancer incidence trends and disparities in the United States: 2000-2010. Cancer Epidemiol. 2015; 39(4): 497-504.

PubMed Abstract | Publisher Full Text | Free Full Text

11. Sano D, Myers JN: Metastasis of squamous cell carcinoma of the oral tongue. Cancer Metastasis Rev. 2007; 26(3-4): 645-62. PubMed Abstract | Publisher Full Text

12. Denis F, Garaud P, Manceau A, et al.: [Prognostic value of the number of involved nodes after neck dissection in oropharyngeal and oral cavity carcinoma]. Cancer Radiother. 2001; 5(1): 12-22. PubMed Abstract | Publisher Full Text

13. Sharma A, Kim JW, Paeng JY: Clinical analysis of neck node metastasis in oral cavity cancer. J Korean Assoc Oral Maxillofac Surg. 2018; 44(6): 282-288. PubMed Abstract | Publisher Full Text | Free Full Text

14. Woolgar JA, Triantafyllou A, Lewis JS Jr, et al.: Prognostic biological features in neck dissection specimens. Eur Arch Otorhinolaryngol. 2013; 270(5): 1581-92. PubMed Abstract | Publisher Full Text

15. Teymoortash A, Werner JA: Current advances in diagnosis and surgical treatment of lymph node metastasis in head and neck cancer. GMS Curr Top Otorhinolaryngol Head Neck Surg. 2012; 11: Doc04. PubMed Abstract | Publisher Full Text | Free Full Text

16. Valastyan S, Weinberg RA: Tumor metastasis: molecular insights and evolving paradigms. Cell. 2011; 147(2): 275-292. PubMed Abstract | Publisher Full Text | Free Full Text

17. Walker C, Mojares E, Del Río Hernández A: Role of Extracellular Matrix in Development and Cancer Progression. Int J Mol Sci. 2018; 19(10): pii: E3028. PubMed Abstract | Publisher Full Text | Free Full Text

18. Lambert AW, Pattabiraman DR, Weinberg RA: Emerging Biological Principles of Metastasis. Cell. 2017; 168(4): 670-691.

PubMed Abstract | Publisher Full Text | Free Full Text

19. Kotwall C, Sako K, Razack MS, et al.: Metastatic patterns in squamous cell cancer of the head and neck. Am J Surg. 1987; 154(4): 439-442. PubMed Abstract | Publisher Full Text

20. Duprez F, Berwouts D, De Neve W, et al:: Distant metastases in head and neck cancer. Head Neck. 2017; 39(9): 1733-1743. PubMed Abstract | Publisher Full Text

21. Park S, Han W, Kim J, et al:: Risk Factors Associated with Distant Metastasis and Survival Outcomes in Breast Cancer Patients with Locoregiona Recurrence. J Breast Cancer. 2015; 18(2): 160-166. PubMed Abstract | Publisher Full Text | Free Full Text

22. Hadzic S, Gojkov-Vukelic M, Pasic E, et al.: Importance of Early Detection of Potentially Malignant Lesions in the Prevention of Oral Cancer. Mater Sociomed. 2017; 29(2): 129-133.

PubMed Abstract | Publisher Full Text | Free Full Text

23. Minhas S, Sajjad A, Kashif M, et al.: Oral Ulcers Presentation in Systemic Diseases: An Update. Open Access Maced J Med Sci. 2019; 7(19): 3341-3347. PubMed Abstract | Publisher Full Text | Free Full Text

24. Macpherson LMD: Raising awareness of oral cancer from a public and health professional perspective. Br Dent J. 2018; 225(9): 809-814.

Publisher Full Text

25. Kramer IR, Lucas RB, Pindborg JJ, et al:: Definition of leukoplakia and related lesions: an aid to studies on oral precancer. Oral Surg Oral Med Oral Pathol. 1978; 46(4): 518-39.

PubMed Abstract | Publisher Full Text

26. Waldron CA, Shafer WG: Leukoplakia revisited. A clinicopathologic study 3256 oral leukoplakias. Cancer. 1975; 36(4): 1386-1392.

PubMed Abstract | Publisher Full Text

27. Bewley AF, Farwell DG: Oral leukoplakia and oral cavity squamous cell carcinoma. Clin Dermatol. 2017; 35(5): 461-467.

PubMed Abstract | Publisher Full Text

28. Thompson L: World Health Organization classification of tumours: pathology and genetics of head and neck tumours. Ear Nose Throat J. 2006; 85(2): 74. PubMed Abstract | Publisher Full Text

29. Gandolfo S, Castellani R, Pentenero M: Proliferative verrucous leukoplakia: a potentially malignant disorder involving periodontal sites. J Periodontol. 2009; 80(2): 274-281.

PubMed Abstract | Publisher Full Text

30. Bagán JV, Murillo J, Poveda R, et al.: Proliferative verrucous leukoplakia: unusual locations of oral squamous cell carcinomas, and field cancerization as shown by the appearance of multiple OSCCs. Oral Oncol. 2004; 40(4): 440-443. PubMed Abstract | Publisher Full Text

31. Neville BW, Day TA: Oral cancer and precancerous lesions. CA Cancer J Clin. 2002; 52(4): 195-215.

PubMed Abstract | Publisher Full Text

32. Warnakulasuriya S: Clinical features and presentation of oral potentially malignant disorders. Oral Surg Oral Med Oral Pathol Oral Radiol. 2018; 125(6): 582-590.

PubMed Abstract | Publisher Full Text

33. Mortazavi $\mathrm{H}$, Baharvand $\mathrm{M}$, Mehdipour M: Oral potentially malignant disorders: an overview of more than 20 entities. J Dent Res Dent Clin Dent Prospects. 2014; 8(1): 6-14.

PubMed Abstract | Publisher Full Text | Free Full Text

34. Yardimci G, Kutlubay Z, Engin B, et al.: Precancerous lesions of oral mucosa. World J Clin Cases. 2014; 2(12): 866-872.

PubMed Abstract | Publisher Full Text | Free Full Text

35. Shafer WG, Waldron CA: Erythroplakia of the oral cavity. Cancer. 1975; 36(3): 1021-1028.

PubMed Abstract | Publisher Full Text

36. Yang SW, Lee YS, Chang LC, et al:: Clinical characteristics of narrow-band imaging of oral erythroplakia and its correlation with pathology. BMC Cancer. 2015; 15: 406

PubMed Abstract | Publisher Full Text | Free Full Text

37. Lapthanasupkul P, Poomsawat S, Punyasingh J: A clinicopathologic study of oral leukoplakia and erythroplakia in a Thai population. Quintessence Int. 2007; 38(8): e448-55

PubMed Abstract | Publisher Full Text

38. Passi D, Bhanot P, Kacker D, et al: Oral submucous fibrosis: Newer proposed classification with critical updates in pathogenesis and management strategies. Natl J Maxillofac Surg. 2017; 8(2): 89-94. PubMed Abstract | Publisher Full Text | Free Full Text

39. Chourasia NR, Borle RM, Vastani A: Concomitant Association of Oral Submucous Fibrosis and Oral Squamous Cell Carcinoma and Incidence of Malignant Transformation of Oral Submucous Fibrosis in a Population of Central India: A Retrospective Study. J Maxillofac Oral Surg. 2015; 14(4): 902-906. PubMed Abstract | Publisher Full Text | Free Full Text

40. Chaturvedi P, Vaishampayan SS, Nair S, et al: Oral squamous cell carcinom arising in background of oral submucous fibrosis: a clinicopathologically distinct disease. Head Neck. 2013; 35(10): 1404-1409. PubMed Abstract | Publisher Full Text

41. Said-Al-Naief N, Rosebush MS, Lynch D: Clinical-pathological conference: case 2. Head Neck Pathol. 2010; 4(3): 221-225. PubMed Abstract | Publisher Full Text | Free Full Text

42. Aghbari SMH, Abushouk Al, Attia A, et al:: Malignant transformation of oral lichen planus and oral lichenoid lesions: A meta-analysis of 20095 patient data. Oral Oncol. 2017; 68: 92-102. PubMed Abstract | Publisher Full Text

43. Mignogna MD, Lo Muzio L, Lo Russo L, et al:: Clinical guidelines in early detection of oral squamous cell carcinoma arising in oral lichen planus: a 5-year experience. Oral Oncol. 2001; 37(3): 262-267. PubMed Abstract | Publisher Full Text

44. Muñoz AA, Haddad RI, Woo SB, et al.: Behavior of oral squamous cell carcinoma in subjects with prior lichen planus. Otolaryngol Head Neck Surg. 2007; 136(3): 401-404. PubMed Abstract | Publisher Full Text

45. Gandini S, Botteri E, lodice S, et al.: Tobacco smoking and cancer: a metaanalysis. Int J Cancer. 2008; 122(1): 155-164. PubMed Abstract | Publisher Full Text 
46. al-Idrissi HY: Head and neck cancer in Saudi Arabia: retrospective analysis of 65 patients. $J$ Int Med Res. 1990; 18(6): 515-519. PubMed Abstract | Publisher Full Text

47. Wang $\mathrm{X}, \mathrm{Xu} \mathrm{J}$, Wang $\mathrm{L}$, et al.: The role of cigarette smoking and alcohol consumption in the differentiation of oral squamous cell carcinoma for the males in China. J Cancer Res Ther. 2015; 11(1): 141-145. PubMed Abstract | Publisher Full Text

48. Llewelyn J, Mitchell R: Smoking, alcohol and oral cancer in south east Scotland: a 10-year experience. Br J Oral Maxillofac Surg. 1994; 32(3): 146-152. PubMed Abstract | Publisher Full Text

49. Seitz HK, Becker P: Alcohol metabolism and cancer risk. Alcohol Res Health. 2007; 30(1): 38-47.

PubMed Abstract | Free Full Text

50. Feller L, Chandran R, Khammissa RA, et al.: Alcohol and oral squamous cell carcinoma. SADJ. 2013; 68(4): 176-180. PubMed Abstract

51. Liu $\mathrm{Y}$, Chen $\mathrm{H}$, Sun Z, et al:: Molecular mechanisms of ethanol-associated oro-esophageal squamous cell carcinoma. Cancer Lett. 2015; 361(2): 164-173. PubMed Abstract | Publisher Full Text | Free Full Text

52. Alharbi F: Incidence of head and neck cancers in Jazan province, Saudi Arabia. Saudi J Otorhinolaryngol Head Neck Surg. 2017; 19(2): 47-50. Reference Source

53. Quadri MF, Alharbi F, Bajonaid AM, et al: Oral squamous cell carcinoma and associated risk factors in Jazan, Saudi Arabia: a hospital based case control study. Asian Pac J Cancer Prev. 2015; 16(10): 4335-4338. PubMed Abstract | Publisher Full Text

54. Scheifele C, Nassar A, Reichart PA: Prevalence of oral cancer and potentially malignant lesions among shammah users in Yemen. Oral Oncol. 2007; 43(1) $42-50$.

PubMed Abstract | Publisher Full Text

55. Al-Hebshi NN, Skaug N: Khat (Catha edulis)-an updated review. Add Biol. 2005; 10(4): 299-307.

PubMed Abstract | Publisher Full Text

56. Alsanosy RM, Mahfouz MS, Gaffar AM: Khat chewing among students of higher education in Jazan region, Saudi Arabia: prevalence, pattern, and related factors. Biomed Res Int. 2013; 2013: 487232. PubMed Abstract | Publisher Full Text | Free Full Text

57. Fasanmade A, Kwok E, Newman L: Oral squamous cell carcinoma associated with khat chewing. Oral Surg Oral Med Oral Pathol Oral Radiol Endod. 2007; 104(1): e53-e55.

PubMed Abstract | Publisher Full Text

58. Sawair FA, Al-Mutwakel A, Al-Eryani K, et al.: High relative frequency of oral squamous cell carcinoma in Yemen: qat and tobacco chewing as its aetiological background. Int J Environ Health Res. 2007; 17(3): 185-195. PubMed Abstract | Publisher Full Text

59. Lukandu OM, Koech LS, Kiarie PN: Oral Lesions Induced by Chronic Khat Use Consist Essentially of Thickened Hyperkeratinized Epithelium. Int J Dent. 2015; 2015: 104812.

PubMed Abstract | Publisher Full Text | Free Full Text

60. Shafagoj YA, Mohammed FI: Levels of maximum end-expiratory carbon monoxide and certain cardiovascular parameters following hubble-bubble smoking. Saudi Med J. 2002; 23(8): 953-8. PubMed Abstract

61. Al Ghobain M, Ahmed A, Abdrabalnabi Z, et al:: Prevalence of and attitudes to waterpipe smoking among Saudi Arabian physicians. East Mediterr Health J. 2018; 24(3): 277-282.

PubMed Abstract | Publisher Full Text

62. Patil S, Awan $\mathrm{KH}$, Arakeri G, et al.: The relationship of "shisha" (water pipe) smoking to the risk of head and neck cancer. J Oral Pathol Med. 2019; 48(4): 278-283.

PubMed Abstract | Publisher Full Text

63. Zaid K, Azar-Maalouf E, Barakat C, et al:: p53 Overexpression in Oral Mucosa in Relation to Shisha Smoking in Syria and Lebanon. Asian Pac J Cancer Prev.
2018; 19(7): 1879-1882.

PubMed Abstract | Publisher Full Text | Free Full Text

64. Al-Amad SH, Awad MA, Nimri O: Oral cancer in young Jordanians: potential association with frequency of narghile smoking. Oral Surg Oral Med Oral Pathol Oral Radiol. 2014; 118(5): 560-565.

PubMed Abstract | Publisher Full Text

65. Goregen M, Akgul HM, Gundogdu C: The cytomorphological analysis of buccal mucosa cells in smokers. Turk J Med Sci. 2011; 41: 205-10. Publisher Full Text

66. Salih MA, Bushra MO, El Nabi AH, et al: Comparison between exfoliative cytology and histopathology in detecting oral squamous cell carcinoma. Saudi J Oral Sci. 2017; 4: 46-50. Publisher Full Text

67. Badvi JA, Kulsoom J, Ujjan IU, et al:: Recent techniques for diagnosis of oral squamous cell carcinoma. EC Microbiology. 2017; 5(5): 165-168. Reference Source

68. Masthan KM, Sankari SL, Babu NA, et al:: How to help the oral pathologist in making an accurate diagnosis. J Clin Diagn Res. 2013; 7(1): 181-184. PubMed Abstract | Publisher Full Text | Free Full Text

69. Fuller C, Camilon R, Nguyen S, et al:: Adjunctive diagnostic techniques for oral lesions of unknown malignant potential: Systematic review with metaanalysis. Head Neck. 2015; 37(5): 755-762. PubMed Abstract | Publisher Full Text

70. Mascitti M, Orsini G, Tosco V, et al.: An Overview on Current Non-invasive Diagnostic Devices in Oral Oncology. Front Physiol. 2018; 9: 1510. PubMed Abstract | Publisher Full Text | Free Full Text

71. Cristaldi M, Mauceri R, Di Fede O, et al:: Salivary Biomarkers for Oral Squamous Cell Carcinoma Diagnosis and Follow-Up: Current Status and Perspectives. Front Physiol. 2019; 10: 1476.

PubMed Abstract | Publisher Full Text | Free Full Text

72. Javaid MA, Ahmed AS, Durand R, et al.: Saliva as a diagnostic tool for oral and systemic diseases. J Oral Biol Craniofac Res. 2016; 6(1): 66-75. PubMed Abstract | Publisher Full Text | Free Full Text

73. Sujir N, Ahmed J, Pai K, et al.: Challenges in Early Diagnosis of Oral Cancer: Cases Series. Acta Stomatol Croat. 2019; 53(2): 174-180. PubMed Abstract | Publisher Full Text | Free Full Text

74. Franzmann EJ, Reategui EP, Carraway KL, et al:: Salivary soluble CD44: a potential molecular marker for head and neck cancer. Cancer Epidemiol Biomarkers Prev. 2005; 14(3): 735-739. PubMed Abstract | Publisher Full Tex

75. Nagler R, Bahar G, Shpitzer T, et al.: Concomitant analysis of salivary tumor markers--a new diagnostic tool for oral cancer. Clin Cancer Res. 2006; 12(13): 3979-3984.

PubMed Abstract | Publisher Full Text

76. Elashoff $\mathrm{D}$, Zhou H, Reiss J, et al:: Prevalidation of salivary biomarkers for oral cancer detection. Cancer Epidemiol Biomarkers Prev. 2012; 21(4): 664-672. PubMed Abstract | Publisher Full Text | Free Full Text

77. Hoffmann TK, Sonkoly E, Homey B, et al.: Aberrant cytokine expression in serum of patients with adenoid cystic carcinoma and squamous cell carcinoma of the head and neck. Head Neck. 2007; 29(5): 472-478. PubMed Abstract | Publisher Full Text

78. Arellano-Garcia ME, Hu S, Wang J, et al:: Multiplexed immunobead-based assay for detection of oral cancer protein biomarkers in saliva. Oral Dis. 2008; 14(8): 705-712.

PubMed Abstract | Publisher Full Text | Free Full Text

79. Gleber-Netto FO, Yakob M, Li F, et al.: Salivary Biomarkers for Detection of Oral Squamous Cell Carcinoma in a Taiwanese Population. Clin Cancer Res. 2016; 22(13): 3340-3347.

PubMed Abstract | Publisher Full Text | Free Full Text

80. Awasthi $\mathrm{N}$ : Role of salivary biomarkers in early detection of oral squamous cell carcinoma. Indian J Pathol Microbiol. 2017; 60(4): 464-8. PubMed Abstract | Publisher Full Text 


\title{
Open Peer Review
}

\section{Current Peer Review Status:}

\section{Version 1}

Reviewer Report 14 April 2020

https://doi.org/10.5256/f1000research.25327.r61966

(C) 2020 Leghari A. This is an open access peer review report distributed under the terms of the Creative Commons Attribution License, which permits unrestricted use, distribution, and reproduction in any medium, provided the original work is properly cited.

\author{
Ali Leghari \\ Department of Community Dentistry, Baqai Dental College, Baqai Medical University, Karachi, \\ Pakistan
}

The article is well written and I would like to accept it. I do have the following suggestions to improve its overall impact.

1. In figure 1: Addition of a clinical picture showing OSCC would benefit the article.

2. It would be better if PVL is mentioned as a distinct form of oral leukoplakia and not as a destructive form.

3. It would be better if areca nut as a risk factor of OSCC also mentioned separately in heading "Common etiological factor of OSCC".

Is the topic of the review discussed comprehensively in the context of the current literature?

Yes

Are all factual statements correct and adequately supported by citations? Yes

Is the review written in accessible language?

Yes

Are the conclusions drawn appropriate in the context of the current research literature? Yes

Competing Interests: No competing interests were disclosed.

I confirm that I have read this submission and believe that I have an appropriate level of 
expertise to confirm that it is of an acceptable scientific standard.

Reviewer Report 14 April 2020

https://doi.org/10.5256/f1000research.25327.r61967

(C) 2020 Qadir F et al. This is an open access peer review report distributed under the terms of the Creative Commons Attribution License, which permits unrestricted use, distribution, and reproduction in any medium, provided the original work is properly cited.

\section{Ambreen Rehman}

Queen Mary University of London, London, UK

\section{Fatima Qadir}

Centre of clinical and diagnostic oral sciences, Institute of Dentistry, Barts \& The London School of Medicine and Dentistry, Queen Mary University of London, London, UK

The review on Oral squamous cell carcinoma is a well written comprehensive article. It summarises the aetiology, metastasis and current diagnostic methods of OSCC. It also sheds light on possible use of salivary proteins to aid diagnosis. All the information provided is scientifically valid.

I would like the author to review the following minor suggested changes:

1. Recheck reference 1, I have not found any content related to the incidence of OSCC or Head and neck cancer.

2. Human Papilloma Virus (HPV) is one of the leading cause of OSCC. It should be included in the aetiology.

Is the topic of the review discussed comprehensively in the context of the current

literature?

Yes

Are all factual statements correct and adequately supported by citations? Yes

Is the review written in accessible language?

Yes

Are the conclusions drawn appropriate in the context of the current research literature? Yes

Competing Interests: No competing interests were disclosed.

Reviewer Expertise: Head and neck oral squamous cell carcinoma, micro-vesicles, Exosomes, oral cancer diagnostics. 
We confirm that we have read this submission and believe that we have an appropriate level of expertise to confirm that it is of an acceptable scientific standard.

Reviewer Report 09 April 2020

https://doi.org/10.5256/f1000research.25327.r61965

(c) 2020 Aljofi F. This is an open access peer review report distributed under the terms of the Creative Commons Attribution License, which permits unrestricted use, distribution, and reproduction in any medium, provided the original work is properly cited.

\section{Faisal Aljofi}

Department of Oncology and Diagnostic Sciences, School of Dentistry, University of Maryland, Baltimore, MD, USA

1. In etiology section: it has been mentioned that there is a various etiological factors that cause OSCC, most of the articles that have been cited are based on epidemiological statistics. So I think it is better to specify that these are based on epidemiological statistics.

2. It has been mentioned that early detection of cancer using certain techniques like salivary bio markers will lead to successful prognosis and treatment, are there any studies showing that there is improved prognosis after early detection? If not then this would be a good way to mention this as a suggestion and future trend to establish studies to show the essential role of early diagnosis.

3. Suggestions to add diagnostic criteria for early detection of OSCC.

Is the topic of the review discussed comprehensively in the context of the current literature?

Yes

Are all factual statements correct and adequately supported by citations?

Yes

Is the review written in accessible language?

Yes

Are the conclusions drawn appropriate in the context of the current research literature? Yes

Competing Interests: No competing interests were disclosed.

I confirm that I have read this submission and believe that I have an appropriate level of expertise to confirm that it is of an acceptable scientific standard. 
The benefits of publishing with F1000Research:

- Your article is published within days, with no editorial bias

- You can publish traditional articles, null/negative results, case reports, data notes and more

- The peer review process is transparent and collaborative

- Your article is indexed in PubMed after passing peer review

- Dedicated customer support at every stage

For pre-submission enquiries, contact research@f1000.com 